\title{
Chiral Mixed Ligand Complexes as Catalysts in the Hydrolysis of Esters
}

\author{
V. S. SHIVANKAR and L. V. GAVALI* \\ Karmaveer Bhaurao Patil College, \\ Sector-15A, Vashi, Navi Mumbai (Maharashtra)- 400 703, India \\ laxmanvg@yahoo.com
}

Received 1 April 2013 / Accepted 30 April 2013

\begin{abstract}
Chiral mixed ligand (CML) metal complexes of the type $\mathrm{MLL}^{\prime} \cdot \mathrm{xH}_{2} \mathrm{O}(\mathrm{x}=1$ or 2$)$, where $\mathrm{M}$ is $\mathrm{Co}(\mathrm{II}) / \mathrm{Ni}(\mathrm{II}), \mathrm{L}$ is deprotonated 8-hydroxyquinoline and $\mathrm{L}^{\prime}$ is a deprotonated poly dentate chiral secondary ligand have been synthesized. The metal complexes have been characterized on the basis of elemental analysis and various physicochemical techniques. The molar conductance values of the complexes in methanol at $10^{-3} \mathrm{M}$ concentration were very low $(<1)$, indicating their non-electrolytic nature. The observed $\mu_{\text {eff }}$ values are suggestive of the tetrahedral/octahedral geometry for the $\mathrm{Co}$ (II) complexes and an octahedral geometry for the $\mathrm{Ni}(\mathrm{II})$ complex. The magnetic moments of the compounds investigated are in agreement with the conclusions based on spectral findings. Hydrolysis of methyl acetate and ethyl acetate was studied by using the complexes as homogeneous catalysts. The rate constants have been obtained by using different catalysts at various temperatures. The activation energy (E) was calculated from the Arrhenius plots. The changes in the enthalpy of activation $\left(\Delta \mathrm{H}^{\ddagger}\right)$, entropy of activation $\left(\Delta S^{\ddagger}\right)$ and free energy of activation $\left(\Delta G^{\ddagger}\right)$ were also calculated. A probable reaction mechanism has also been suggested.
\end{abstract}

Keywords: Chiral mixed ligand complexes, Hydrolysis of esters

\section{Introduction}

The use of CML metal complexes in the kinetic study of catalytic decomposition of $\mathrm{H}_{2} \mathrm{O}_{2}$ is studied recently ${ }^{1-2}$. Some metal ligand complexes are found to catalyze reactions such as oxidation, oxidative cleavage, hydroformylation, etc. and have shown catalyse like activity in decomposition of hydrogen peroxide. It is well established that ternary complexes play a decisive role in the activation of enzymes and also in the storage and transport of active substances ${ }^{3}$. The binary and ternary transition metal complexes have shown biological activity ${ }^{4}$. During recent years metal complexes of some N-/O- donor ligands have attracted considerable attention because of their greater antifungal and antibacterial activities than those of the parent ligands ${ }^{5-7}$. Ternary complexes containing an amino acid as a secondary ligand are of significance as they are potential models for enzyme-metal ion substrate complexes ${ }^{8}$. 
The present paper reports the synthesis and characterization of CML $\mathrm{Co}$ (II)/Ni(II) complexes prepared by using 8-hydroxyquinoline as primary ligand and some chiral polydentate ligands as secondary ligands. Hydrolysis of methyl acetate and ethyl acetate was studied by using the complexes as homogeneous catalysts. A probable reaction mechanism has also been suggested.

\section{Experimental}

Most of the chemicals used were of AR grade. Laboratory grade chemicals, whenever used, were purified by standard methods. Solvents such as ethanol, methanol and chloroform were purified and dried according to standard procedures 9

\section{Preparation of mixed ligand complexes}

To a blue-colored ethanol $\left(10 \mathrm{~cm}^{3}\right)$ solution of metal(II) chloride hexahydrate $(1 \mathrm{mmol})$, an ethanol $\left(10 \mathrm{~cm}^{3}\right)$ solution of 8 -hydroxyquinoline $(1 \mathrm{mmol})$ was added. The mixture was stirred and kept in a boiling water bath for 10 minutes, during which time it turned green. To this solution an aqueous $\left(10 \mathrm{~cm}^{3}\right)$ solution of the secondary ligand $(1 \mathrm{mmol})$ was added. This mixture (1:1:1 molar proportion) was heated in a hot water bath till the temperature reached $50{ }^{\circ} \mathrm{C}$. The mixture was cooled and the solid was filtered, washed with ice-cold water followed by 1:1 ethanol: water. The complexes thus prepared were dried under vacuum.

\section{Instrumentation}

The complexes were analysed for the metal contents, $\mathrm{C}, \mathrm{H}$ and $\mathrm{N}$ using standard procedures. The molar conductance values were measured in methanol $\left(10^{-3} \mathrm{M}\right)$ on a model CM-180 Elico digital conductivity meter. Room temperature magnetic susceptibilities were measured by Guoy balance using $\mathrm{Hg}\left[\mathrm{Co}(\mathrm{SCN})_{4}\right]$ as the calibrant. The specific optical rotation values for the complexes were determined in methanol solution $(0.01 \%)$ on a Jasco DIP-140 polarimeter. Electronic absorption spectra in methanol $\left(10^{-4} \mathrm{M}\right)$ and chloroform $\left(10^{-3} \mathrm{M}\right)$ solution in the ultraviolet and visible range, respectively, were measured on a Shimadzu UV-160A and spectronic-20 spectrophotometer. Reflectance spectra of the solid complexes in the visible region were recorded against $\mathrm{BaSO}_{4}$ on a Shimadzu UV-2100 spectrophotometer. FT-IR spectra were recorded in $\mathrm{KBr}$ discs on a Perkin-Elmer FT-IR spectrophotometer model 160. Thermal studies of the complexes were made on a Mettler TC 10A TA processor by recording the change in weight of the complexes on increasing the temperature up to $700{ }^{\circ} \mathrm{C}$ at a heating rate of $10^{\circ} \mathrm{C} / \mathrm{min}$.

\section{Hydrolysis of esters}

To a solution of $\mathrm{Co}(\mathrm{II}) / \mathrm{Ni}(\mathrm{II})$ complex, prepared by dissolving known amount of it in a solvent mixture of $20 \mathrm{~cm}^{3} \mathrm{DMF}$ and $20 \mathrm{~cm}^{3}$ distilled water (and whose $\mathrm{pH}$ was adjusted to $2.5), 5 \mathrm{~cm}^{3}$ of methyl acetate/ethyl acetate was added and the content stirred uniformly. The extent of the reaction was estimated by withdrawing $5 \mathrm{~cm}^{3}$ of reaction mixture at regular intervals of time and titrating it against standard $\mathrm{NaOH}$ solution using phenolphthalein as an indicator. Reaction was carried out at 30,40 and $50{ }^{\circ} \mathrm{C}$ in a thermostat with an accuracy of $\pm 0.01{ }^{0} \mathrm{C}$. The quantity of catalysts used was in the range $0.01-0.04 \mathrm{~g}$.

The reaction rates were compared with the rates obtained by using $\mathrm{HCl}$ as conventional catalyst. $40 \mathrm{~cm}^{3}$ of $\mathrm{HCl}$ of known strength was taken in a stoppered bottle and $5 \mathrm{~cm}^{3}$ of ester was added to it. The extent of reaction taking place was obtained as mentioned above. Reaction was carried out at 30,40 and $50{ }^{\circ} \mathrm{C}$ using $0.002,0.01$ and $0.05 \mathrm{M} \mathrm{HCl}$. 
The activation energy $(E)$ was calculated from the Arrhenius plots. The changes in the enthalpy of activation $\left(\Delta \mathrm{H}^{\ddagger}\right)$, entropy of activation $\left(\Delta \mathrm{S}^{\ddagger}\right)$ and free energy of activation $\left(\Delta \mathrm{G}^{\ddagger}\right)$ were also calculated.

\section{Results and Discussion}

\section{Characterization of metal complexes}

The synthesis of mixed ligand $\mathrm{Co}(\mathrm{II}) / \mathrm{Ni}(\mathrm{II})$ complexes may be represented as follows:

$$
\begin{array}{ll}
\mathrm{M}(\mathrm{II})+\mathrm{HL}+\mathrm{HL} \longrightarrow & \mathrm{M}(\mathrm{II}) \mathrm{LL}^{\prime}+2 \mathrm{H}^{+} \\
1: 1: 1 & \text { mixed ligand complex }
\end{array}
$$

(where $\mathrm{M}$ is $\mathrm{Co} / \mathrm{Ni}, \mathrm{HL}$ is 8 - hydroxyquinoline and $\mathrm{HL}^{\prime}$ is a secondary ligand ).

All of the complexes are non-hygroscopic stable solids. They are coloured and thermally stable (Table 1). The elemental analysis data (Table 1) of metal complexes is consistent with their general formulation as mixed ligand complexes $M L^{\prime} \cdot \mathrm{xH}_{2} \mathrm{O}$. The specific rotation values, $[\alpha]_{D}$, for all of the complexes in methanol solution $(0.01 \%)$ were found to be positive or negative (Table 1). This indicates that the specific rotation of the complexes is due to the corresponding chiral amino acid moiety. The molar conductance values of the complexes in methanol at $10^{-3} \mathrm{M}$ concentration are very low $(<1)$, indicating their non-electrolytic nature ${ }^{10}$.

Table 1. Observed color, decomposition temperature, magnetic moment and elemental

\begin{tabular}{|c|c|c|c|c|c|c|c|c|c|c|}
\hline \multirow{2}{*}{ Complex } & \multirow{2}{*}{$\begin{array}{c}\text { Empirical } \\
\text { formula } \\
\text { (Formula Wt.) }\end{array}$} & \multirow{2}{*}{$\begin{array}{l}\frac{0}{0} \\
\frac{0}{2} \\
i\end{array}$} & \multirow{2}{*}{$\frac{\dot{0}}{0}$} & \multirow{2}{*}{ 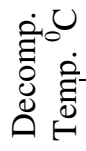 } & \multicolumn{4}{|c|}{$\begin{array}{l}\text { Elemental Analysis, \% } \\
\text { Found (Calculated) }\end{array}$} & \multirow{2}{*}{$\frac{\pi}{\sigma}$} & \multirow{2}{*}{$\stackrel{\overbrace{}}{\sum_{0}}$} \\
\hline & & & & & M & $\mathrm{C}$ & $\mathrm{N}$ & $\mathrm{H}$ & & \\
\hline $\begin{array}{l}\mathrm{Co}(\mathrm{Q}) \\
(\mathrm{Dex})] \cdot 2 \mathrm{H}_{2} \mathrm{O}\end{array}$ & $\begin{array}{c}\mathrm{C}_{15} \mathrm{H}_{21} \mathrm{CoNO}_{9} \\
(417.93) \\
\end{array}$ & 89 & $\begin{array}{l}\text { Light } \\
\text { yellow }\end{array}$ & 270 & $\begin{array}{c}14.12 \\
(14.10) \\
\end{array}$ & $\begin{array}{c}43.00 \\
(43.07) \\
\end{array}$ & $\begin{array}{c}3.40 \\
(3.35) \\
\end{array}$ & $\begin{array}{c}5.27 \\
(5.02) \\
\end{array}$ & & 4.54 \\
\hline $\begin{array}{l}\mathrm{Co}(\mathrm{Q}) \\
(\mathrm{Fru})] \cdot 2 \mathrm{H}_{2} \mathrm{O} \\
\end{array}$ & $\begin{array}{c}\mathrm{C}_{15} \mathrm{H}_{21} \mathrm{CoNO}_{9} \\
(417.93) \\
\end{array}$ & 88 & $\begin{array}{c}\text { Light } \\
\text { yellow }\end{array}$ & 275 & $\begin{array}{c}14.12 \\
(14.10) \\
\end{array}$ & $\begin{array}{l}43.00 \\
(43.07) \\
\end{array}$ & $\begin{array}{c}3.40 \\
(3.35) \\
\end{array}$ & $\begin{array}{c}5.27 \\
(5.02) \\
\end{array}$ & -220.0 & 4.61 \\
\hline $\begin{array}{l}\mathrm{Co}(\mathrm{Q}) \\
(\mathrm{Man})] \cdot 2 \mathrm{H}_{2} \mathrm{O}\end{array}$ & $\begin{array}{c}\mathrm{C}_{15} \mathrm{H}_{23} \mathrm{CoNO}_{9} \\
(419.93) \\
\end{array}$ & 85 & $\begin{array}{l}\text { Light } \\
\text { yellow }\end{array}$ & & $\begin{array}{c}14.23 \\
(14.79) \\
\end{array}$ & $\begin{array}{c}43.01 \\
(41.29) \\
\end{array}$ & $\begin{array}{c}3.21 \\
(3.97) \\
\end{array}$ & $\begin{array}{c}5.30 \\
(5.69) \\
\end{array}$ & -222.2 & 5.10 \\
\hline $\begin{array}{l}{[\mathrm{Co}(\mathrm{Q})} \\
(\mathrm{Tar})] \cdot \mathrm{H}_{2} \mathrm{O} \\
\end{array}$ & $\begin{array}{c}\mathrm{C}_{13} \mathrm{H}_{13} \mathrm{CoNO}_{8} \\
(369.93) \\
\end{array}$ & 89 & $\begin{array}{l}\text { Light } \\
\text { yellow }\end{array}$ & & $\begin{array}{c}15.72 \\
(15.30) \\
\end{array}$ & $\begin{array}{c}42.35 \\
(46.11) \\
\end{array}$ & $\begin{array}{c}3.75 \\
(3.27) \\
\end{array}$ & $\begin{array}{c}3.71 \\
(3.67) \\
\end{array}$ & +236.2 & 4.92 \\
\hline $\begin{array}{l}{[\mathrm{Ni}(\mathrm{Q})(\mathrm{Dex})]} \\
2 \mathrm{H}_{2} \mathrm{O}\end{array}$ & $\begin{array}{c}\mathrm{C}_{15} \mathrm{H}_{21} \mathrm{NiNO}_{9} \\
(417.69)\end{array}$ & 90 & Green & 230 & $\begin{array}{c}14.25 \\
(14.10) \\
\end{array}$ & $\begin{array}{c}43.00 \\
(43.07) \\
\end{array}$ & $\begin{array}{c}3.55 \\
(3.35) \\
\end{array}$ & $\begin{array}{c}5.89 \\
(5.62)\end{array}$ & +225.9 & 2.96 \\
\hline
\end{tabular}
analysis data of the metal complexes ${ }^{\mathrm{a}}$

\section{Magnetic studies}

The observed $\mu_{\text {eff }}$ values (Table 1) are suggestive of the tetrahedral/octahedral geometry for the $\mathrm{Co}(\mathrm{II})$ complexes and an octahedral geometry for the Ni(II) complex. The magnetic moments of the compounds investigated are in agreement with the conclusions based on spectral findings.

\section{Infrared spectra}

The FT-IR spectra of the metal complexes were recorded as $\mathrm{KBr}$ discs over the range 4000-400 $\mathrm{cm}^{-1}$. On the basis of reported infra-red spectra of ligands and their metal complexes some of the important bands have been assigned ${ }^{8,11-13}$. 
A broad band observed in the region between $3362-3315 \mathrm{~cm}^{-1}$ due to asymmetric (asym) and symmetric (sym) O-H stretching modes and a strong band around $1575-1573 \mathrm{~cm}^{-1}$ due to $\mathrm{H}-\mathrm{O}-\mathrm{H}$ bending vibrations are indicative of the presence of lattice water ${ }^{14}$.

The merging and broadening of bands was found to be a common feature of transition metal-saccharide complexes. The spectra of all the complexes with saccharides showed broad bands in the $\mathrm{O}-\mathrm{H}$ and $\mathrm{C}-\mathrm{H}$ regions, indicating a merging of individual bands. The spectral characteristics are similar to those observed with other $1^{\text {st }}$ row transition metal complexes. The structural vibrations of the intermolecular hydrogen bonded $\mathrm{O}-\mathrm{H}$ groups of the free saccharides were affected ionization and exhibited a broad but nearly symmetrical band at $\sim 3400 \mathrm{~cm}^{-1}$. The strongly coupled ring vibrational frequencies for bending modes $\mathrm{COH}, \mathrm{CH}_{2}$ and $\mathrm{CCH}$ of the free saccharides (1460-1340 $\mathrm{cm}^{-1}$ ) showed merging at $1400 \mathrm{~cm}^{-1}$ upon complex formation. Similarly, the C-O and C-C stretching vibrations in the region 1140-990 $\mathrm{cm}^{-1}$ were also merged at $\sim 1050 \mathrm{~cm}^{-1}$ upon complex formation, in contrast to the sharp bands observed for the free saccharides and other metal-saccharide adducts. The anomeric region $\left(950-500 \mathrm{~cm}^{-1}\right)$ showed very weak marker bands of mostly $\alpha$-anomer. It was clear from the spectra that the saccharides were involved in coordination through some deprotonated $-\mathrm{OH}$ groups as observed from the broad bands in $\mathrm{v}(\mathrm{O}-\mathrm{H})$ region, $3500-3200 \mathrm{~cm}^{-1}$. On the basis of coordinating abilities of the various saccharides reported, a 3,4-trans-diol arrangement has been proposed for CML complexes with glucose and fructose. The $\mathrm{C}-\mathrm{O}$ and $\mathrm{C}-\mathrm{C}$ stretching vibrations in the region 1140-990 $\mathrm{cm}^{-1}$ were also merged at $\sim 1050 \mathrm{~cm}^{-1}$ upon complex formation, in contrast to the sharp bands observed for the free saccharides and other metal-saccharide adducts.

The protonated carboxyl group in tartaric acid has an absorption at $1740 \mathrm{~cm}^{-1}$, which is typical of $\mathrm{C}=\mathrm{O}$ stretching vibrations of $-\mathrm{COOH}$. The corresponding coordinated carboxylate in the complex shows absorption at lower frequency i.e. $1636 \mathrm{~cm}^{-1}$, which leads to the conclusion that the complexation takes place by deprotonation of carboxylic group of tartaric acid moiety. The shifting of stretching and bending frequency $\mathrm{v}(\mathrm{C}-\mathrm{O})$ towards lower wave number i.e. $1106 \mathrm{~cm}^{-1}$ in the complex with tartaric acid indicates the coordination of secondary $-\mathrm{OH}$ group via oxygen with the metal ion.

An important feature of infrared spectra of the metal complexes is the absence of the band at $\sim 3440 \mathrm{~cm}^{-1}$ due to $\mathrm{O}-\mathrm{H}$ stretching vibration of the $\mathrm{OH}$ group of HQ. This observation leads to the conclusion that the complex formation takes place by deprotonation of the hydroxyl group of HQ moiety. In the spectrum of free HQ ligand the $v(\mathrm{C}-\mathrm{O})$ band is observed at $\sim 1160 \mathrm{~cm}^{-1}$. It is reported that for the mixed ligand complexes of $\mathrm{Co}(\mathrm{II}), \mathrm{Mn}(\mathrm{II}), \mathrm{Cu}(\mathrm{II}), \mathrm{Ni}(\mathrm{II})$ and $\mathrm{Vo}(\mathrm{II})$ with $\mathrm{HQ}$, this band is observed at $\sim 1125 \mathrm{~cm}^{-1}$. The position of this band undergoes variation depending on the metal complex under study. In the present investigation, a strong $v(\mathrm{C}-\mathrm{O})$ band is observed in the range $1107-1103 \mathrm{~cm}^{-1}$ in the spectra of the complexes, indicating the presence of 8-hydroxyquinolate group in the complexes coordinating through its nitrogen and oxygen atoms as uni negative bidentate ligand. The $\mathrm{v}(\mathrm{C}=\mathrm{N})$ mode observed at $1580 \mathrm{~cm}^{-1}$ in the spectrum of free HQ ligand is found to be shifted to lower wave number i.e. $1500-1499 \mathrm{~cm}^{-1}$ in the spectra of the CML complexes, suggesting coordination through the tertiary nitrogen donor of HQ. The in-plane and out-of-plane ring deformation modes observed at $\sim 500$ and $\sim 780 \mathrm{~cm}^{-1}$, respectively, in the spectrum of $\mathrm{HQ}$ are shifted to higher wave numbers i.e. $\sim 505$ and $\sim 787 \mathrm{~cm}^{-1}$, respectively, confirming coordination through the nitrogen atom of HQ with the metal ion.

Some new bands of weak intensity observed in the regions around 657-595 and 466$415 \mathrm{~cm}^{-1}$ may be ascribed to the M-O and M-N vibrations, respectively ${ }^{15}$. Some of the important IR bands and their tentative assignments are shown in Table 2. 
Table 2. Some important infrared spectral bands $\left(\mathrm{cm}^{-1}\right)$ of the complexes ${ }^{\mathrm{a}}$

\begin{tabular}{|c|c|c|c|c|c|c|c|c|c|}
\hline Complex & $\begin{array}{c}v(\mathrm{O}-\mathrm{H}) \\
\left(\mathrm{H}_{2} \mathrm{O}\right)\end{array}$ & $\begin{array}{c}v \\
(\mathrm{C}=\mathrm{O})\end{array}$ & $v(\mathrm{C}-\mathrm{O})$ & $\begin{array}{c}v \\
(\mathrm{HOH})\end{array}$ & $\begin{array}{c}v(\mathrm{C}=\mathrm{N}) \\
(\mathrm{HQ})\end{array}$ & $\begin{array}{c}v \\
(\mathrm{C}-\mathrm{O}) \\
(\mathrm{HQ}) \\
\end{array}$ & $\begin{array}{c}v \\
(\mathrm{C}-\mathrm{H})^{\mathrm{a}} \\
(\mathrm{HQ}) \\
\end{array}$ & $\begin{array}{c}\mathrm{V} \\
(\mathrm{C}-\mathrm{H})^{\mathrm{b}} \\
(\mathrm{HQ})\end{array}$ & $v(\mathrm{M}-\mathrm{N}) v(\mathrm{M}-\mathrm{O})$ \\
\hline $\begin{array}{c}{[\mathrm{Co}(\mathrm{Q})} \\
(\mathrm{Dex})] \cdot 2 \mathrm{H}_{2} \mathrm{O} \\
\end{array}$ & $3315 \mathrm{w}$ & - & - & $1573 \mathrm{~s}$ & $1499 \mathrm{~s}$ & $1106 \mathrm{~s}$ & $786 w$ & $506 \mathrm{w}$ & $602^{\mathrm{c}} \mathrm{w} \quad 410^{\mathrm{c}} \mathrm{w}$ \\
\hline $\begin{array}{c}{[\mathrm{Co}(\mathrm{Q})} \\
(\mathrm{Fru})] \cdot 2 \mathrm{H}_{2} \mathrm{O}\end{array}$ & $3362 \mathrm{w}$ & - & - & $1575 \mathrm{~s}$ & $1500 \mathrm{~s}$ & $1106 \mathrm{~s}$ & $788 w$ & $505 \mathrm{w}$ & $571^{\mathrm{c}} \mathrm{w} \quad 425^{\mathrm{c}} \mathrm{w}$ \\
\hline $\begin{array}{c}{[\mathrm{Co}(\mathrm{Q})} \\
(\mathrm{Man})] \cdot 2 \mathrm{H}_{2} \mathrm{O}\end{array}$ & $3322 \mathrm{w}$ & - & - & $1573 \mathrm{~s}$ & $1500 \mathrm{~m}$ & $1107 \mathrm{~s}$ & $787 \mathrm{w}$ & $505 \mathrm{w}$ & $600^{\mathrm{c}} \mathrm{w} \quad 407^{\mathrm{c}} \mathrm{w}$ \\
\hline $\begin{array}{c}{[\mathrm{Co}(\mathrm{Q})} \\
(\mathrm{Tar})] \cdot \mathrm{H}_{2} \mathrm{O} \\
\end{array}$ & $3320 \mathrm{w}$ & $1636 \mathrm{~m}$ & $1106 \mathrm{~s}$ & $1574 \mathrm{~m}$ & $1499 \mathrm{~m}$ & $1106 \mathrm{~s}$ & $787 \mathrm{w}$ & $505 \mathrm{w}$ & $605^{\mathrm{c}} \mathrm{w} \quad 415^{\mathrm{c}} \mathrm{w}$ \\
\hline $\begin{array}{c}{[\mathrm{Ni}(\mathrm{Q})} \\
(\mathrm{Dex})] \cdot 2 \mathrm{H}_{2} \mathrm{O} \\
\end{array}$ & $3360 \mathrm{w}$ & - & - & $1575 \mathrm{~m}$ & $1500 \mathrm{~s}$ & $1107 \mathrm{~s}$ & $788 w$ & $506 \mathrm{w}$ & $575^{\mathrm{c}} \mathrm{w} \quad 410^{\mathrm{c}} \mathrm{w}$ \\
\hline
\end{tabular}

${ }^{a}$ Where a: out-of-plane, $b$ : in-plane, $c$ : amino acid, $d: H Q$, s: strong, m: medium, w: weak

\section{Electronic absorption spectra}

The electronic spectra of the metal complexes in methanol solution, recorded in the ultraviolet region, exhibit intra ligand and charge transfer transitions in the range around $25,940-48,192 \mathrm{~cm}^{-1}$ and near $25940 \mathrm{~cm}^{-1}$, respectively. The electronic absorption spectra of $\mathrm{Co}$ (II) complexes in chloroform solution in the visible and near infrared region shows three transition bands in the region around $25,000 \mathrm{~cm}^{-1}, 16,000 \mathrm{~cm}^{-1}$ and $12,000 \mathrm{~cm}^{-1}$ respectively, while that of the $\mathrm{Ni}$ (II) complexes show two transition bands in the region around $25,000 \mathrm{~cm}^{-1}$ and $12,195 \mathrm{~cm}^{-1}$, respectively.

The diffuse reflectance spectra of Co(II) complexes with dextrose and fructose show the $\mathrm{d}-\mathrm{d}$ transition bands (Table 2) in the region around 12,900 and $17,500 \mathrm{~cm}^{-1}$ and those with mannitol and tartaric acid in the region around 17,000 and $20,000 \mathrm{~cm}^{-1}$, which are assigned to transitions ${ }^{4} \mathrm{~A}_{2}(\mathrm{~F}) \rightarrow{ }^{4} \mathrm{~T}_{1}(\mathrm{~F})\left(\mathrm{v}_{2}\right)$ and ${ }^{4} \mathrm{~A}_{2}(\mathrm{~F}) \rightarrow{ }^{4} \mathrm{~T}_{1}(\mathrm{P})\left(\mathrm{v}_{3}\right)$, respectively. The Ni(II) complexes show two transition bands (Table 2) in the region around 12,700 and 18,900 $\mathrm{cm}^{-1}$, which are ascribed to transitions ${ }^{3} \mathrm{~A}_{2 \mathrm{~g}}(\mathrm{~F}) \rightarrow{ }^{3} \mathrm{~T}_{1 \mathrm{~g}}(\mathrm{~F})\left(\mathrm{v}_{2}\right)$ and ${ }^{3} \mathrm{~A}_{2 \mathrm{~g}}(\mathrm{~F}) \rightarrow{ }^{3} \mathrm{~T}_{1 \mathrm{~g}}(\mathrm{P})\left(\mathrm{v}_{3}\right)$, respectively. As the $v_{1}$ band occurs at low energy, usually in the range not accessible due to instrumental limitations, it is not observed in the present cases. Various spectral parameters like Dq, B' and $\beta$ have been calculated by using the values of $v_{2}$ and $v_{3}$ transitions, according to the equations of König ${ }^{16}$. From the values of Dq and B', the energy of transition $v_{1}$ has been calculated (Table 3).

Table 3. Diffuse reflectance spectral data for the complexes

\begin{tabular}{ccccccc}
\hline Complex & $v_{1} \mathrm{~cm}^{-1 \mathrm{a}}$ & $v_{2} \mathrm{~cm}^{-1}$ & $v_{3} \mathrm{~cm}^{-1}$ & $\mathrm{Dq}, \mathrm{cm}^{-1}$ & $\mathrm{~B}, \mathrm{~cm}^{-1}$ & $\beta$ \\
\hline$[\mathrm{Co}(\mathrm{Q})($ Dex $)] \cdot 2 \mathrm{H}_{2} \mathrm{O}$ & 6,286 & 12,953 & 17,391 & 628.6 & 765.7 & 0.788 \\
{$[\mathrm{Co}(\mathrm{Q})(\mathrm{Fru})] \cdot 2 \mathrm{H}_{2} \mathrm{O}$} & 6,339 & 12,853 & 17,543 & 633.9 & 758.5 & 0.781 \\
{$[\mathrm{Co}(\mathrm{Q})(\mathrm{Man})] \cdot 2 \mathrm{H}_{2} \mathrm{O}$} & 8.047 & 17,241 & 20,202 & 919.3 & 886.6 & 0.913 \\
{$[\mathrm{Co}(\mathrm{Q})($ Tar $)] \cdot \mathrm{H}_{2} \mathrm{O}$} & 7,838 & 16,806 & 20,000 & 896.7 & 885.9 & 0.912 \\
{$[\mathrm{Ni}(\mathrm{Q})($ Dex $)] \cdot 2 \mathrm{H}_{2} \mathrm{O}$} & 6,874 & 12,658 & 18,867 & 687.4 & 726.6 & 0.697 \\
\hline \multicolumn{7}{c}{ Calculated values }
\end{tabular}

The observed electronic transitional energies are suggestive of tetrahedral/octahedral geometry for $\mathrm{Co}$ (II) complexes and an octahedral geometry for $\mathrm{Ni}(\mathrm{II})$ complex. The present $\beta$ values are less than unity, suggesting an appreciable covalent character of the M-L bonds ${ }^{17}$. 


\section{Thermal studies}

The thermograms (TG) of the complexes have been recorded in flowing nitrogen atmosphere at the heating rate of $10{ }^{\circ} \mathrm{C} / \mathrm{min}$ on approximately $10 \mathrm{mg}$ samples. All the complexes investigated show similar behavior in their TG and Differential Thermal Analysis (DTA) studies.

The complexes, in general, show the first mass loss attributed to dehydration, in the temperature range 109 to $129{ }^{\circ} \mathrm{C}$ (Table 4). The completion of the reaction was found to be around $555{ }^{\circ} \mathrm{C}$. On the basis of the results of the physicochemical studies, the bonding and structure in the metal complexes can be represented as shown in Figure 1.

Table 4. Thermal data for the complexes

\begin{tabular}{lccc}
\hline \multirow{2}{*}{ Complex } & Temperature & \multicolumn{2}{c}{ Weight loss due to $\mathrm{H}_{2} \mathrm{O}, \%$} \\
\cline { 3 - 4 } & Range, ${ }^{\circ} \mathrm{C}^{\mathrm{a}}$ & Calculated & Observed \\
\hline$[\mathrm{Co}(\mathrm{Q})($ Dex $)] \cdot 2 \mathrm{H}_{2} \mathrm{O}$ & $106-187$ & 8.6 & 8.8 \\
{$[\mathrm{Co}(\mathrm{Q})(\mathrm{Fru})] \cdot 2 \mathrm{H}_{2} \mathrm{O}$} & $103-178$ & 8.6 & 8.3 \\
{$[\mathrm{Co}(\mathrm{Q})(\mathrm{Man})] \cdot 2 \mathrm{H}_{2} \mathrm{O}$} & $105-180$ & 8.4 & 8.2 \\
{$[\mathrm{Co}(\mathrm{Q})(\mathrm{Tar})] \cdot \mathrm{H}_{2} \mathrm{O}$} & $111-181$ & 4.9 & 5.0 \\
{$[\mathrm{Ni}(\mathrm{Q})($ Dex $)] \cdot 2 \mathrm{H}_{2} \mathrm{O}$} & $121-194$ & 8.9 & 9.0 \\
\hline
\end{tabular}

${ }^{a}$ First mass loss step during decomposition

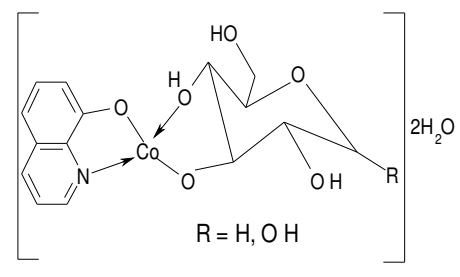

$\underline{\mathrm{a}}$

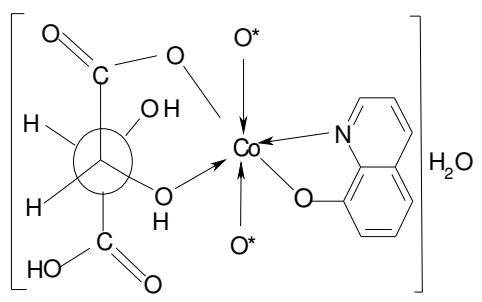

c

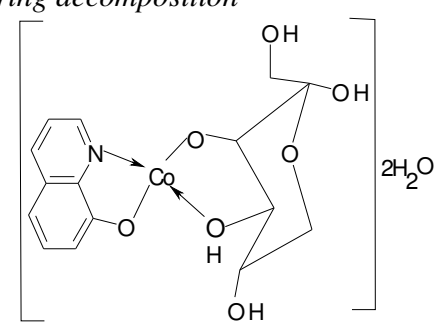

b

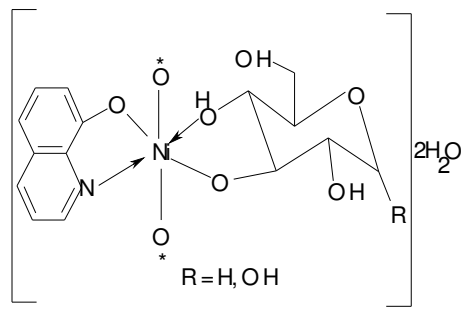

d

Figure 1. Probable structure for mixed ligand complexes (a) $[\mathrm{Co}(\mathrm{HQ})(\mathrm{Dex})] \cdot 2 \mathrm{H}_{2} \mathrm{O}$, b) $[\mathrm{Co}(\mathrm{HQ})(\mathrm{Fru})] \cdot 2 \mathrm{H}_{2} \mathrm{O}$, (c) $[\mathrm{Co}(\mathrm{HQ})(\mathrm{Tar})] \cdot \mathrm{H}_{2} \mathrm{O}$ and (d) $[\mathrm{Ni}(\mathrm{HQ})(\mathrm{Dex})] \cdot 2 \mathrm{H}_{2} \mathrm{O}$

\section{Hydrolysis of esters}

Hydrolysis of methyl acetate and ethyl acetate was studied by using complexes as homogeneous catalysts. Keeping the quantity of ester and the temperature constant, when the quantity of catalyst was varied in the range $0.01-0.04 \mathrm{~g}$, the value of $k$ increased with increase in the quantity of the catalyst (Table 5). 
Table 5. Influence of the amount of catalyst on the hydrolysis of ethyl acetate by a representative complex $[\mathrm{Co}(\mathrm{Q})($ Dex $)] \cdot 2 \mathrm{H}_{2} \mathrm{O}$

\begin{tabular}{cc}
\hline Amount of catalyst, $\mathrm{g}$ & Specific reaction rate, $k \times 10^{-4}, \mathrm{~min}^{-1}$ \\
\hline 0.010 & 0.50 \\
0.020 & 0.80 \\
0.030 & 1.29 \\
0.040 & 1.69 \\
\hline
\end{tabular}

${ }^{a}$ Temperature: $313 \mathrm{~K}$, volume of ethyl acetate: $5.0 \mathrm{~cm}^{3}$

The plot of rate constant versus the amount of catalyst (Figure 2) is linear showing that the rate constant is directly proportional to the amount of catalyst used in the reaction. A similar correlation has been established in the case of aliphatic esters by Walvekar et al. ${ }^{18}$.

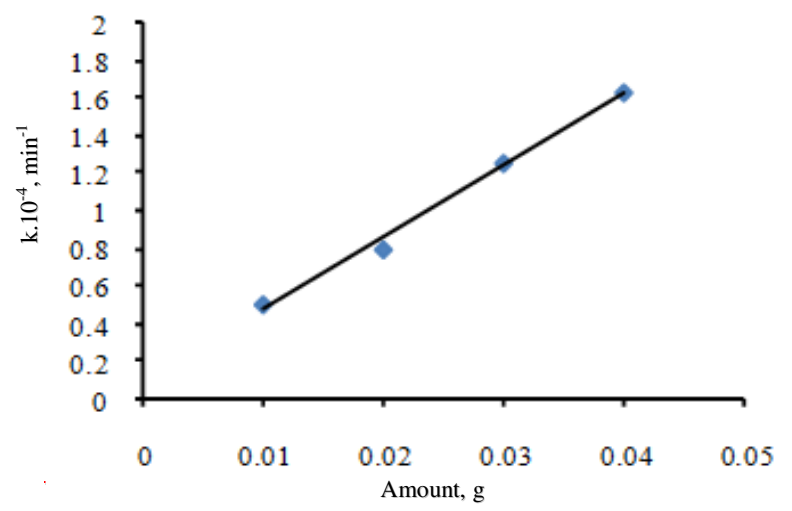

Figure 2. Plot of rate of reaction versus amount of catalyst $[\mathrm{Co}(\mathrm{Q})(\mathrm{Dex})] \cdot 2 \mathrm{H}_{2} \mathrm{O}$ (Temperature: $313 \mathrm{~K}$, volume of ethyl acetate: $5.0 \mathrm{~cm}^{3}$

Hammett et al. ${ }^{19}$ have shown that the hydrolysis of ethyl acetate in presence of $\mathrm{HCl}$ is first order in [ester]. In the present study, it is found that with the present $\mathrm{Co}$ (II) complexes also the hydrolysis is first order in [ester] as shown by the linear plot of log (a-x) against $\mathrm{t}$. The rate constants for the hydrolysis of methyl acetate and ethyl acetate obtained by using different catalysts at various temperatures are given in Table 6 and 7 respectively. Keeping the quantity of the catalyst and ester constant, when the temperature was varied in the range $30-50{ }^{\circ} \mathrm{C}$, the value of $\mathrm{k}$ increased with increase in temperature. As a catalyst, however, $\mathrm{HCl}$ is more efficient as compared to the mixed ligand complexes.

Table 6. Kinetics of hydrolysis ${ }^{\mathrm{a}}$ of methyl acetate in presence of CMLM complexes as homogeneous catalysts ${ }^{\mathrm{b}}$

\begin{tabular}{ccccccc}
\hline Complex & $\begin{array}{c}\mathrm{T} \\
\mathrm{K}\end{array}$ & $\begin{array}{c}\mathrm{k} \times 10^{-2} \\
\mathrm{~min}^{-1}\end{array}$ & $\begin{array}{c}\mathrm{E} \\
\mathrm{kJ} \cdot \mathrm{mol}^{-1}\end{array}$ & $\begin{array}{c}\Delta \mathrm{H}^{\neq} \\
\mathrm{kJ}^{2} \mathrm{~mol}^{-1}\end{array}$ & $\begin{array}{c}\Delta \mathrm{S}^{-1} \\
\mathrm{JK}^{-1} \cdot \mathrm{mol}^{-1}\end{array}$ & $\begin{array}{c}\Delta \mathrm{G}^{\neq} \\
\mathrm{kJ}^{2} \mathrm{~mol}^{-1}\end{array}$ \\
\hline$[\mathrm{Co}(\mathrm{Q})(\mathrm{Dex})] \cdot 2 \mathrm{H}_{2} \mathrm{O}$ & 303 & 0.72 & & & & \\
& 323 & 1.49 & 55.84 & 53.24 & -173.41 & 107.51 \\
& 303 & 0.95 & & & & \\
{$[\mathrm{Co}(\mathrm{Q})(\mathrm{Fru})] \cdot 2 \mathrm{H}_{2} \mathrm{O}$} & 313 & 1.80 & 48.73 & 46.13 & -194.83 & 107.11 \\
\hline
\end{tabular}




\begin{tabular}{ccccccc}
\hline & 323 & 3.00 & & & & \\
{$[\mathrm{Co}(\mathrm{Q})(\mathrm{Man})] \cdot 2 \mathrm{H}_{2} \mathrm{O}$} & 303 & 0.65 & & & \\
& 313 & 1.15 & 48.82 & 46.22 & -197.81 & 108.13 \\
& 323 & 2.08 & & & & \\
{$[\mathrm{Co}(\mathrm{Q})(\mathrm{Tar})] \cdot \mathrm{H}_{2} \mathrm{O}$} & 303 & 0.83 & & & & \\
& 313 & 1.38 & 38.29 & 35.69 & -230.56 & 107.85 \\
& 323 & 2.11 & & & & \\
{$[\mathrm{Ni}(\mathrm{Q})(\mathrm{Dex})] \cdot 2 \mathrm{H}_{2} \mathrm{O}$} & 313 & 0.57 & & & & \\
& 323 & 0.92 & 35.90 & 33.30 & -242.07 & 109.07 \\
\hline
\end{tabular}

${ }^{a}$ Volume of ester taken : $5 \mathrm{~cm}^{3},{ }^{b}$ Amount of catalyst : $40 \mathrm{mg}$

Table 7. Kinetics of hydrolysis ${ }^{\mathrm{a}}$ of ethyl acetate in presence of CMLM complexes as homogeneous catalysts ${ }^{\text {b }}$

\begin{tabular}{|c|c|c|c|c|c|c|}
\hline Complex & $\begin{array}{l}\mathrm{T} \\
\mathrm{K}\end{array}$ & $\begin{array}{l}\mathrm{k} \times 10^{-2} \\
\min ^{-1}\end{array}$ & $\begin{array}{c}\mathrm{E} \\
\mathrm{kJ} \cdot \mathrm{mol}^{-1}\end{array}$ & $\begin{array}{c}\Delta \mathrm{H}^{\neq} \\
\mathrm{kJ} \cdot \mathrm{mol}^{-1}\end{array}$ & $\begin{array}{c}\Delta \mathrm{S}^{\neq} \\
\mathrm{JK}^{-1} \cdot \mathrm{mol}^{-1}\end{array}$ & $\begin{array}{c}\Delta \mathrm{G}^{\neq} \\
\mathrm{kJ} \cdot \mathrm{mol}^{-1}\end{array}$ \\
\hline \multirow{3}{*}[\mathrm{Co}(\mathrm{Q})(\mathrm{Dex})]{$\cdot 2 \mathrm{H}_{2} \mathrm{O}$} & 303 & 0.64 & \multirow{3}{*}{57.44} & \multirow{4}{*}{54.84} & \multirow{3}{*}{-169.07} & \multirow{4}{*}{107.76} \\
\hline & 313 & 1.35 & & & & \\
\hline & 323 & 2.49 & & & & \\
\hline \multirow{4}{*}[\mathrm{Co}(\mathrm{Q})(\mathrm{Fru})]{$\cdot 2 \mathrm{H}_{2} \mathrm{O}$} & 303 & 0.69 & \multirow{3}{*}{52.76} & & \multirow{4}{*}{-183.20} & \\
\hline & 313 & 1.45 & & \multirow[t]{3}{*}{50.16} & & \multirow[t]{3}{*}{107.50} \\
\hline & 323 & 2.81 & & & & \\
\hline & 303 & 0.54 & & & & \\
\hline \multirow[t]{3}{*}[\mathrm{Co}(\mathrm{Q})(\mathrm{Man})]{$\cdot 2 \mathrm{H}_{2} \mathrm{O}$} & 313 & 1.11 & \multirow[t]{3}{*}{51.06} & \multirow[t]{3}{*}{48.46} & \multirow[t]{3}{*}{-191.35} & \multirow[t]{3}{*}{108.35} \\
\hline & 323 & 1.92 & & & & \\
\hline & 303 & 0.68 & & & & \\
\hline \multirow[t]{3}{*}[\mathrm{Co}(\mathrm{Q})(\mathrm{Tar})]{$\cdot \mathrm{H}_{2} \mathrm{O}$} & 313 & 1.36 & \multirow[t]{3}{*}{40.96} & \multirow[t]{3}{*}{38.36} & \multirow[t]{3}{*}{-222.52} & \multirow[t]{3}{*}{108.01} \\
\hline & 323 & 2.03 & & & & \\
\hline & 303 & 0.51 & & & & \\
\hline \multirow[t]{2}{*}[\mathrm{Ni}(\mathrm{Q})(\mathrm{Dex})]{$\cdot 2 \mathrm{H}_{2} \mathrm{O}$} & 313 & 0.79 & \multirow[t]{2}{*}{35.49} & \multirow[t]{2}{*}{32.89} & \multirow[t]{2}{*}{-244.09} & \multirow[t]{2}{*}{109.29} \\
\hline & 323 & 1.19 & & & & \\
\hline
\end{tabular}

${ }^{a}$ Volume of ester taken : $5 \mathrm{~cm}^{3},{ }^{b}$ Amount of catalyst : $40 \mathrm{mg}$

It has been found that the rate of hydrolysis of methyl acetate is higher than that of ethyl acetate for all the catalysts, indicating that steric hindrance affects the rate of the reaction. The rate is reduced by the bulkier ethyl group near the reaction $\operatorname{site}^{20}$, in addition to which there would be contribution due to normal inductive and resonance effects of the substituent.

It is observed that $\Delta H^{\ddagger}$ values are closer to $E$ values in accordance with absolute reaction rate theory for solution. The value of $\Delta G^{\neq}$has been found to be higher in all the cases and not much difference has been found in two systems. The values of $\Delta S^{\ddagger}$ were found to be negative in all the cases indicating that molecules in transition state are more ordered than the reactants in ground state.

In the hydrolysis of esters, the activated complexes are probably quite polar, owing to the ionization of the carbonyl group. Owing to the electrostriction of the solvent by the activated complexes in such reactions, the entropies of activation are low. Such reactions are accelerated by an increase in the dielectric constant of the solvent. Another reason for 
strongly negative values may be the partial immobilization of water molecules in the activated state, brought about as a result of the distribution of charges on activated complex. Following mechanism may be suggested for the complex catalyzed hydrolysis of esters.

$$
\begin{aligned}
\mathrm{M}(\mathrm{II}) \mathrm{LL} \text { ' + Ester } \frac{\mathrm{k}_{1}}{\mathrm{k}_{-1}} \mathrm{M}(\mathrm{II}) \mathrm{LL} \text { '-Ester } \\
\mathrm{M}(\mathrm{II}) \mathrm{LL} \text { '-Ester }+\mathrm{H}^{+} \stackrel{\mathrm{k}_{2}}{\longrightarrow} \mathrm{M}(\mathrm{II}) \mathrm{LL}^{\prime} \text {-Acid }+\mathrm{ROH}
\end{aligned}
$$

On the basis of steady state approximation,

$$
[\mathrm{M}(\mathrm{II}) \mathrm{LL} \text {-Ester }]=\frac{\mathrm{k}_{1}[\text { Ester }]\left[\mathrm{M}(\mathrm{II}) \mathrm{LL}{ }^{\prime}\right]}{\mathrm{k}_{-1}+\mathrm{k}_{2}\left[\mathrm{H}^{+}\right]}
$$

The rate of the reaction is given as

$$
\mathrm{dx} / \mathrm{dt}=\frac{\mathrm{k}_{1} \mathrm{k}_{2}[\text { Ester }]\left[\mathrm{M}(\mathrm{II}) \mathrm{LL}^{\prime}\right]}{\mathrm{k}_{-1}+\mathrm{k}_{2}\left[\mathrm{H}^{+}\right]}
$$

Under the present experimental conditions, [Ester] is much larger than $\left[\mathrm{H}^{+}\right]$.

Hence, $\mathrm{k}_{-1}+\mathrm{k}_{2}\left[\mathrm{H}^{+}\right]$can be neglected. Eq. (5) then changes to Eq. (6).

$$
\mathrm{dx} / \mathrm{dt}=\mathrm{k}_{1} \mathrm{k}_{2} \text { [Ester] [M(II)LL'] }
$$

The reaction seems to be bimolecular as ester and catalyst are involved in the kinetics of the reaction. The above mechanism predicts a first order dependence on [M(II)LL']. According to Eq. (6), a plot of rate of the reaction against [M(II)LL'] should be linear. This is found to be so, as seen from the plot in Figure 2, indicating the validity of the rate law (6) and hence of the proposed mechanism.

\section{References}

1. Ram R N, Gupta J R and Prasad B B, Indian J Chem., 1979, 17, 29.

2. Shivankar V S, Burungale A S, Rajmane M M and Gavali L V, Arch Appl Sci Res., 2012, 4(5), 2289-2298.

3. Hughes M N, Coordination Compounds in Biology. In Comprehensive Coordination Chemistry; Wilkinson G, Gillard R D and McCleverty J A Eds., Pergamon Press: Oxford, 1987, 6, 541-754.

4. Odola A J and Woods J A O, Arch Appl Sci Res., 2011, 3(4), 463.

5. Shivankar V S and Thakkar N V, Acta Poloniae Pharmaceutica (Drug Research. Poland), 2004, 61(2), 127-133.

6. Shivankar V S, Vaidya R B, Dharwadkar S R and Thakkar N V, Synthesis and reactivity in Inorganic and Metal-Organic Chemistry (Marcel Dekker, New York), 2003, 33(9), 1597-1622.

7. Sakthilatha D and Rajavel R, Chem Sci Trans., 2013, 2(3), 711-726.

8. Freeman H C, Metal Complexes of Amino Acids and Peptides. In Inorganic Biochemistry; Eichhorn G L, Ed., Elsevier Scientific: Amsterdam, 1973, 1, 121-166.

9. Furniss B S, Hannford A J, Smith P W G and Tatchell R, Solvents and Regeants, Vogels Text books of Practicals Organic Chemistry, $5^{\text {th }}$ Ed., ELBS Logman, London 1989, 395.

10. Geary W J, Coord Chem Rev., 1971, 7(1), 81-122.

11. Shivankar V S, Gavali L V, Yadav S P and Thakkar N V, IOSR J Appl Chem., 2013, 3(6), 31-39. 
12. Shivankar V S and Thakkar N V, Indian J Chem., 2006, 45A, 382-387.

13. Nakamoto K, Morimoto Y and Martell A E, J Am Chem Soc., 1961, 83, 4528-4532.

14. Nakamoto K, Lattice Water and Aquo and Hydroxo Complexes, In Infrared and Raman Spectra of Inorganic and Coordination Compounds, $4^{\text {th }}$ Ed., John-Wiley and Sons: New York, 1986, 227-231.

15. Hamrit H, Djebbar-Sid S, Benali-Baitich O, Khan M A and Bouet G, Synth React Inorg Met-Org Chem., 2000, 30(10), 1835-1848.

16. König E, The Nephelauxetic Effect, In Structure and Bonding; Hemmerich P, Jørgensen C K, Neilands J B, Nybolm Ronald S, Reinen D and Williams R J P, Eds., Springer-Verlag: New York, 1971, 9, 175-212.

17. Sutton D, Further Aspects: Covalency in Transition Metal Complexes. In Electronic Spectra of Transition Metal Complexes; McGraw-Hill: London, 1965, 150-163.

18. Walwekar S P and Halgeri A B, J Indian Chem Soc., 1973, 50, 246,

19. Hammet L P and Huskel V C, J Am Chem Soc., 1941, 71, 1285.

20. Ingold C K, Structure and Mechanism in Organic Chemistry, Cornell University Press, Ithsks, New York, 1953, 335. 